Research Article

\title{
Microplasma Synthesis of Antibacterial Active Silver Nanoparticles in Sodium Polyacrylate Solutions
}

\author{
Mariana Shepida (D), Orest Kuntyi $\left(D\right.$, Yuriy Sukhatskiy ${ }^{(D)}$, Artur Mazur $(D$, \\ and Martyn Sozanskyi
}

Lviv Polytechnic National University, Lviv 79013, Ukraine

Correspondence should be addressed to Mariana Shepida; maryana_shepida@ukr.net

Received 12 August 2021; Accepted 4 October 2021; Published 19 October 2021

Academic Editor: Spyros P. Perlepes

Copyright ( 2021 Mariana Shepida et al. This is an open access article distributed under the Creative Commons Attribution License, which permits unrestricted use, distribution, and reproduction in any medium, provided the original work is properly cited.

\begin{abstract}
The great demand for functional, particularly biologically active, metal nanoparticles has led to the search for technologically effective, green, and controlled methods of synthesizing these metal nanoparticles. Plasma glow discharge is one of the most promising techniques in this direction. The results of studies based on the synthesis of colloidal solutions of stabilized silver nanoparticles (AgNPs) by the microplasma method in solutions of a nontoxic surfactant sodium polyacrylate (NaPA) are presented. It is shown that AgNPs with a size of $2-20 \mathrm{~nm}$ are formed in solutions of $0.05-0.2 \mathrm{mmol} \cdot \mathrm{L}^{-1} \mathrm{AgNO}_{3}+5 \mathrm{~g} \cdot \mathrm{L}^{-1} \mathrm{NaPA}$ at $U=250 \mathrm{~V}$ by tungsten cathode plasma glow discharge. At $20^{\circ} \mathrm{C}$, the yellow solutions are formed with $\lambda_{\max } \approx 410 \mathrm{~nm}$, which are stable during long-term storage. It was found that the process of AgNPs formation corresponds to a first-order reaction on the $\mathrm{AgNO}_{3}$ concentration. Its value has little effect on the geometry of nanoparticles, so the $\mathrm{Ag}(\mathrm{I})$ concentration in solution is one of the main factors influencing the rate of microplasma synthesis of AgNPs. The antimicrobial activity of synthesized AgNPs solutions against strains of Escherichia coli, Staphylococcus aureus, and Candida albicans was established.
\end{abstract}

\section{Introduction}

Metal nanoparticles, especially silver nanoparticles, demonstrate high efficiency in medicine [1-3], sensing [4], catalysis [5], and the agrifood sector [6]. Considering the dependence of the functional properties of MNPs on their shape and size, and in the case of $\mathrm{M}_{1} \mathrm{M}_{2} \mathrm{NPs}$, also dependent on the content of components, significant attention has been paid in the last decade to synthesis methods. After all, they are decisive in forming the structure (composition) of nanoparticles and, accordingly, their properties. Therefore, the controlled synthesis of nanoparticles is one of the main criteria in choosing a method. The defining criteria also include engineering and "green" technology. The latter is the most studied for the use of these three major biological sources: plant extract [5, 7], bacteria [2, 3, 6, 8], and fungi [9]. All of them contain components, which are necessary for the synthesis of colloidal solutions of stabilized metal nanoparticles with the help of reductants, which reduce metal ions (1) and surfactants, which after the formation of MNCs and MNPs (2), provide their stabilization (3).

$$
\begin{gathered}
\mathrm{M}^{\mathrm{n}+}+\text { ne (biol.reduc.) } \longrightarrow \mathrm{M}^{0} \\
\mathrm{mM}^{0} \longrightarrow \mathrm{M}_{m}^{0} \\
\mathrm{M}_{m}^{0}+\text { biol.surf. } \longrightarrow \text { Agn@biol.surf. }
\end{gathered}
$$

Sonochemical and sonoelectrochemical production of nanoparticles [10] and plasma glow discharge [11-13] are effective for increasing the rate of processes similar to (1)-(3). Plasma electrolysis is one of the relatively new and promising methods for the synthesis of nanomaterials. Significant attention is paid to the microplasma, which is characterized by a relatively low temperature and, at the same time, high "density" of electrons. This is especially important for synthesizing colloidal solutions of metal nanoparticles using surfactants. Plasma electrolysis allows 
the controlled formation of particle geometry, which is one of the main requirements of modern nanotechnology. It is also worth noting that plasma meets the requirements of green technologies. This is because plasma does not provide for the use of reducing reagents

A feature of the microplasma is the generation of electrons $\left(\mathrm{e}^{-}\right)$during the discharge, which are hydrated in aqueous solutions (4). The latter $\left(\mathrm{e}^{-}\right.$aq $)$reduce metal ions (5) and cause the formation of $\mathrm{H}$. and $\mathrm{OH}$ radicals and new compounds, in particular, $\mathrm{H}_{2} \mathrm{O}_{2}$ [14]. Some of them are reducing agents for many metal ions (6) and (7). Microplasma synthesis is characterized by its high rate and the absence of a chemical reductant, which minimizes the number of precursors. This method allows using surfactants as stabilizers of MNCs and MNPs, which allows a controlled influence on the formation of their geometry during the stages of nucleation and growth (8).

$$
\begin{gathered}
\mathrm{e}^{-}+\mathrm{H}_{2} \mathrm{O} \longrightarrow \mathrm{e}_{\mathrm{aq}}^{-} \\
\mathrm{M}^{\mathrm{n}+}+\mathrm{ne}_{\mathrm{aq}}^{-} \longrightarrow \mathrm{M}^{0} \\
\mathrm{M}^{\mathrm{n}+}+\mathrm{nH} \cdot \longrightarrow \mathrm{M}^{0}+\mathrm{nH}^{+} \\
\mathrm{M}^{\mathrm{n}+}+\mathrm{nH}_{2} \mathrm{O}_{2} \longrightarrow \mathrm{M}^{0}+\mathrm{nH}_{2} \mathrm{O}+\mathrm{n} / 2 \mathrm{O}_{2} \\
\mathrm{mM}^{0}+\text { surf. } \longrightarrow \text { Mm }(\mathrm{MNCs@surf.}) \longrightarrow \ldots \\
\longrightarrow \text { MNPs@surf. }
\end{gathered}
$$

The microplasma glow discharge method is used to synthesize mainly noble metal nanoparticles [14-30]. Studies in recent years indicate the possibility of obtaining nanoparticles from nonferrous metals [31-35]. The microplasma method is efficient for the synthesis of bimetal nanoparticles [36-44]. The synthesis of MNPs is often carried out in solutions containing surfactants or stabilizers (Table 1) that are nontoxic or of natural origin.

Surfactants are one of the main factors influencing the formation of MNCs and MNPs, as well as their functional properties and stability during long-term storage $[33,45-52]$. The aim of the work is to study the regularities of microplasma synthesis of silver nanoparticles in sodium polyacrylate solutions and establish the conditions of their stable formation. Polyacrylate is a nontoxic synthetic polymeric anionic surfactant that is known to be an effective stabilizer for MNPs [50-56].

\section{Experimental}

Plasma synthesis of colloidal solutions of silver nanoparticles was performed in a thermostated reactor (Figure 1) with a volume of $100 \mathrm{ml}$ under continuous agitation at $20^{\circ} \mathrm{C}$. The platinum plate was used as an anode and tungsten $(99.9 \%$ purity) wire ( $\varnothing=0.1 \mathrm{~mm}$ with a working length of $5 \mathrm{~mm}$ ) as a cathode. The following electrolytes were used for research: 0.05-0.2 $\mathrm{mmol} \cdot \mathrm{L}^{-1} \mathrm{AgNO}_{3}$ and $5 \mathrm{~g} \cdot \mathrm{L}^{-1} \mathrm{NaPA}$ (pH8). The acidity value of the solutions was adjusted with a $1 \mathrm{~mol} \cdot \mathrm{L}^{-1}$ solution of $\mathrm{CH}_{3} \mathrm{COONa}$.
The synthesis was performed at $U=$ constant $=250 \mathrm{~V}$. The values of current and voltage over time during the glow discharge were measured with a recorder (MTech ADCUI18), as shown in Figure 2.

TEM images were obtained using a transmission electron microscope JEM-I230 (JEOL, Tokyo, Japan) with an acceleration voltage of $80 \mathrm{kV}$. The samples for TEM investigations were prepared by drying $0.05 \mu \mathrm{L}$ of silver sol on the carbon grid at room temperature. The diameters of obtained AgNPs were determined using TEM images by comparing individual particle sizes with the scales presented on images. Theoretical calculations and processing of experimental data were carried out using the software Inconico Screen Calipers 4.0 and OriginPro 8.0. The statistical histograms were obtained using the Origin software pack with standard deviation values as nanoparticle size. In addition, NP size and density were determined by using the public domain Java image processing program Image 2 .

The antibacterial activity of AgNPs was evaluated against Gram-negative Escherichia coli (E. coli) and Gram-positive bacteria Staphylococcus aureus (S. aureus) and Candida albicans (C. albicans). To do this, the bacteria were inoculated into Petri dishes with a solid selective nutrient medium for each species of microorganisms: yellow-salt agar for the culture of S. aureus, Endo agar for the culture of E. coli, and Sabouraud Agar for Candida albicans. Inoculation was performed after 1, 6, 18, and 48 hours of contact of bacteria with $0.8 \mathrm{~mm}$ solution of AgNPs. All the biological material was incubated at $310 \mathrm{~K}$ for 24 hours in a bacteriological incubator. Antibacterial activity was indexed by counting the number of microorganisms (CFU/mL).

\section{Results and Discussion}

At $\mathrm{pH}>6$, the structural elements in the polymer chain of polyacrylate transform from the form of $\left(-\mathrm{CH}_{2}-\mathrm{CH}-\mathrm{COOH}\right)_{\mathrm{n}}$ into the anionic form of $\left(-\mathrm{CH}_{2}-\mathrm{CH}-\mathrm{COO}^{-}\right)_{n}$. The fraction of the anionic form increases with an increase in the concentration of $\mathrm{OH}^{-}$ions [52]. In sodium polyacrylate solutions, $\mathrm{Ag}^{+}$cations form soluble $\left[\mathrm{Ag}_{\mathrm{m}} \mathrm{PA}\right]^{(\mathrm{n}-\mathrm{m})-}$ complexes $[50,51,53]$. The latter are transformed into stabilized nanoclusters and nanoparticles (9) during microplasma glow discharge due to the reduction of $\mathrm{Ag}(\mathrm{I})$ to $\mathrm{Ag}(0)$ by hydrated electrons and generated radicals and compounds. Stabilization occurs due to the formation of surface complexes between the $\left[-\mathrm{COO}^{-}\right]$ polymer chain of polyacrylate and silver atoms of AgNCs and AgNPs with the formation of a continuous protective layer of polymer surfactant [52].

$$
\begin{aligned}
{\left[\mathrm{Ag}_{\mathrm{m}} \mathrm{PA}\right]^{(\mathrm{n}-\mathrm{m})-}+} & \left(\mathrm{me}_{\mathrm{aq}}^{-}, \mathrm{mH} \cdot, \mathrm{mH}_{2} \mathrm{O}_{2}\right) \longrightarrow\left[\mathrm{Ag}(0)_{\mathrm{m}} \mathrm{PA}\right]^{\mathrm{n}-} \\
& (\text { AgNCs@PA,AgNPs@PA). }
\end{aligned}
$$

During microplasma glow discharge, yellow solutions are formed with an absorption maximum of $\sim 410 \mathrm{~nm}$, the value of which practically does not change during synthesis and long-term storage (Figure 3 ). 
TABLE 1: Conditions of microplasma synthesis of MNPs and $M_{1} M_{2} N P s$ in aqueous solutions and their characteristics.

\begin{tabular}{|c|c|c|c|c|c|c|}
\hline $\begin{array}{l}\text { MNPs, } \\
\mathrm{M}_{1} \mathrm{M}_{2} \mathrm{NPs}\end{array}$ & Precursor & Stabilizer & Type plasma U, V & $\begin{array}{l}\text { Max. abs. peak }\left(\lambda_{\max }\right) \\
(\mathrm{nm})\end{array}$ & $\begin{array}{l}\text { Particle shape and size } \\
(\mathrm{nm})\end{array}$ & Ref. \\
\hline \multirow{7}{*}{ AgNPs } & $\mathrm{AgNO}_{3}$ & SC & $30 \mathrm{kV}, 9.1 \mathrm{kHz}$ & $369-416$ & $5.4-17.8$ & {$[14]$} \\
\hline & $\mathrm{AgNO}_{3}, \mathrm{EtOH}$ & - & 6000 & $403,412,420$ & $8-10$ & {$[15]$} \\
\hline & $\mathrm{AgNO}_{3}$ & PVA & $1500-2500$ & $\sim 410$ & $10 \pm 7$ & {$[16]$} \\
\hline & $\mathrm{AgNO}_{3}$ & - & $\begin{array}{c}50 \mathrm{kHz} \text { and } 2.5 \mu \mathrm{s}, 3500 \\
(\max )\end{array}$ & $\sim 400-410$ & Spherical, $\sim 10$ & {$[17]$} \\
\hline & $\begin{array}{l}\text { Ag sacrificial } \\
\text { electrode }\end{array}$ & PVP & $175-275$ & $394-417$ & $5-10$ & {$[18]$} \\
\hline & $\mathrm{AgNO}_{3}$ & PEC, SDS & 1100 & $409.4,409.8$ & $\begin{array}{l}9.33 \pm 3.37 \text { PEC-AgNPs } \\
28.3 \pm 11.7 \text { SDS-AgNP }\end{array}$ & {$[19]$} \\
\hline & $\begin{array}{l}\text { Ag sacrificial } \\
\text { electrode }\end{array}$ & - & $\begin{array}{l}\text { Bipolar pulses } 3.8 \mathrm{kV} \text {, } \\
5 \mathrm{kHz}\end{array}$ & $410.03-415.39$ & $25-350$ & {$[20]$} \\
\hline \multirow{8}{*}{ AuNPs } & $\begin{array}{l}\text { Au sacrificial } \\
\text { electrode }\end{array}$ & $\begin{array}{l}\text { Without } \\
\text { stabilizer }\end{array}$ & Plasma sputtering, $20 \mathrm{kHz}$ & 511 & Spherical, $\sim 3.5$ & {$[21]$} \\
\hline & $\mathrm{H}\left[\mathrm{AuCl}_{4}\right]$ & Lysine & Pulsed discharge plasma & $510-550$ & $<20$ & {$[22]$} \\
\hline & $\mathrm{H}\left[\mathrm{AuCl}_{4}\right]$ & $\begin{array}{l}\text { Without } \\
\text { stabilizer }\end{array}$ & From $\sim 2000$ to $\sim 800$ & $\begin{array}{c}\text { From } 532 \text { to } 581 \text { (from } \\
2.5 \mu \mathrm{M} \text { to } 1 \mathrm{mM} \\
\mathrm{HAuCl}_{4} \text { ) }\end{array}$ & $5-200$ & {$[23]$} \\
\hline & $\mathrm{H}\left[\mathrm{AuCl}_{4}\right]$ & $\begin{array}{l}\text { Without } \\
\text { stabilizer }\end{array}$ & 5000 & $552 \pm 1 ; 532 \pm 1$ & $3.2 \pm 0.4 ; 0.8 \pm 0.5$ & {$[24]$} \\
\hline & $\mathrm{H}\left[\mathrm{AuCl}_{4}\right]$ & $\begin{array}{l}\text { GEL, PVP, } \\
\text { PVA }\end{array}$ & $1100-1300$ & $531,534,535$ & $27,73,92$ & {$[25]$} \\
\hline & $\mathrm{H}\left[\mathrm{AuCl}_{4}\right]$ & SDS & $1600,2400,3200$ & - & 150 NPs (1 nm NCs) & {$[26]$} \\
\hline & $\mathrm{H}\left[\mathrm{AuCl}_{4}\right]$ & SC & $6800,90 \mathrm{kHz}$ & $584,566,535$ & $\begin{array}{c}18.2 \pm 9.0,32.9 \pm 14.1 \\
180.6 \pm 20.5\end{array}$ & {$[27]$} \\
\hline & $\mathrm{H}\left[\mathrm{AuCl}_{4}\right]$ & Fructose & $\begin{array}{l}2000 \text { to ignite the } \\
\text { microplasma }\end{array}$ & $\sim 530$ & $\sim 33\left(25^{\circ} \mathrm{C}\right), 37\left(70^{\circ} \mathrm{C}\right)$ & {$[28]$} \\
\hline PtNPs & Pt electrode & - & $\begin{array}{c}\text { Low-voltage, low- } \\
\text { frequency technique: } 440 \text {, } \\
500-100 \mathrm{~Hz}\end{array}$ & - & $\leq 10$ & [29] \\
\hline $\begin{array}{l}\text { PtNPs } \\
\text { PdNPs }\end{array}$ & $\begin{array}{l}\mathrm{H}_{2}\left[\mathrm{PtCl}_{6}\right] \\
\quad \mathrm{PdCl}_{2}\end{array}$ & $\begin{array}{l}\text { Dextran and } \\
\text { without }\end{array}$ & 15000 peak-to-peak with a & - & $\begin{array}{c}3-5 \\
3-15\end{array}$ & [30] \\
\hline RhNPs & $\mathrm{RhCl}_{3}$ & stabilizer & frequency of $25 \mathrm{kHz}$ & & $4.7 \pm 1$ & \\
\hline CuNPs & $\mathrm{CuCl}_{2}$ & GEL & $900,20 \mathrm{kHz}$ frequency & $\sim 580$ & $\begin{array}{l}\text { Spherical }(33.7 \pm 5.8) \text {, } \\
\text { cubic }(19.2 \pm 3.3) \text {, and } \\
\text { hexagonal }(20.3 \pm 2.9)\end{array}$ & {$[31]$} \\
\hline \multirow{2}{*}{ NiNPs } & $\mathrm{Ni}\left(\mathrm{NO}_{3}\right)_{2}$ & - & 70 & 362 and 380 & Spherical, $\sim 15$ & [32] \\
\hline & $\mathrm{NiCl}_{2}$ & CTAB, SDS & $250,25-30 \mathrm{kHz}$ & - & $20-100$ & [33] \\
\hline ZnNPs & $\begin{array}{l}\text { Zn sacrificial } \\
\text { electrode }\end{array}$ & $\begin{array}{l}\text { Without } \\
\text { stabilizer }\end{array}$ & 70 & - & $13.97-22.64$ & {$[34]$} \\
\hline MnNPs & $\mathrm{MnCl}_{2}$ & СТАВ & $\begin{array}{l}\text { Pulsed discharge, 250.10, } \\
30 \mathrm{kHz}\end{array}$ & - & $5-10,20-50$ & {$[35]$} \\
\hline $\begin{array}{l}(\mathrm{PtM}) \mathrm{NPs} \\
(M=\mathrm{cu}, \mathrm{ag}, \\
\mathrm{pd})\end{array}$ & $\begin{array}{l}\text { Sucrifical } \\
\text { electrodes }\end{array}$ & - & $\begin{array}{l}\text { Pulsed plasma discharge, } \\
\text { 1000, } 20 \mathrm{kHz}\end{array}$ & - & $4-6$ & {$[36]$} \\
\hline (PtAg) NPs & $\begin{array}{l}\text { Sucrifical Pt and } \\
\text { Ag electrodes }\end{array}$ & - & $\begin{array}{c}1000,30 \mathrm{kHz} \text {. pulse } \\
\text { duration from } 1.3 \text { to } \\
2.3 \mathrm{~ms}\end{array}$ & - & $<5$ & {$[37]$} \\
\hline$(\mathrm{AgPt}) \mathrm{NPs}$ & $\begin{array}{l}\text { Sucrifical Ag } \\
\text { and } \mathrm{Pt} \\
\text { electrodes }\end{array}$ & SDS & $\begin{array}{l}\text { Unipolar pulsed dc to } \\
\text { electrodes, } 500,3 \mu \mathrm{s}, \\
15 \mathrm{kHz}\end{array}$ & $406.28-414.63$ & $\sim 5$ & {$[38]$} \\
\hline (PtPd)NPs & $\begin{array}{l}\text { Sucrifical Pt and } \\
\text { Pd electrodes }\end{array}$ & - & $\begin{array}{l}\text { 700, pulse width and } \\
\text { frequency were } 2 \mu \text { s and } \\
20 \mathrm{kHz}\end{array}$ & - & $2-3$ & [39] \\
\hline$(\mathrm{PtAu}) \mathrm{NPs}$ & $\begin{array}{l}\text { Sucrifical Pt and } \\
\text { Au electrodes }\end{array}$ & PEG & $\begin{array}{l}800 \text { (breakdown voltage) } \\
\text { pulsed DC } 10-20 \mathrm{kHz} \\
\quad \text { (width } 1-2 \text { ls) }\end{array}$ & - & $1.5 \pm 1.0$ & {$[40]$} \\
\hline (AuPd)NPs & $\begin{array}{l}\mathrm{H}\left[\mathrm{AuCl}_{4}\right] \text { and } \\
\mathrm{H}_{2}\left[\mathrm{PdCl}_{4}\right]\end{array}$ & TCI & $1500 \mathrm{~W}$ & - & $\sim 3$ & {$[41]$} \\
\hline
\end{tabular}


TABLE 1: Continued.

\begin{tabular}{|c|c|c|c|c|c|c|}
\hline $\begin{array}{l}\text { MNPs, } \\
\mathrm{M}_{1} \mathrm{M}_{2} \mathrm{NPs}\end{array}$ & Precursor & Stabilizer & Type plasma U, V & $\begin{array}{c}\text { Max. abs. peak }\left(\lambda_{\max }\right) \\
(\mathrm{nm})\end{array}$ & $\begin{array}{c}\text { Particle shape and size } \\
(\mathrm{nm})\end{array}$ & Ref. \\
\hline$(\mathrm{NiCu}) \mathrm{NPs}$ & $\begin{array}{l}\mathrm{Ni}\left(\mathrm{NO}_{3}\right)_{2} \text { and } \\
\mathrm{Cu}\left(\mathrm{NO}_{3}\right)_{2}\end{array}$ & CTAB & & - & Spherical, 50-200 & [42] \\
\hline$(\mathrm{CoNi}) \mathrm{NPs}$ & $\begin{array}{c}\text { Sucrifical Co } \\
\text { and } \mathrm{Ni} \\
\text { electrodes }\end{array}$ & - & $7 \mathrm{kV}, 10 \mathrm{~Hz}$ & - & $>100$ & [43] \\
\hline $\begin{array}{l}(\mathrm{NiCu}) \mathrm{NPs} \\
(\mathrm{NiCr}) \mathrm{NPs}\end{array}$ & $\begin{array}{l}\text { Sucrifical CuNi } \\
\text { electrodes } \\
\text { Sucrifical NiCr } \\
\text { electrodes }\end{array}$ & - & 160 & - & $<200$ & [44] \\
\hline
\end{tabular}

CTAB, cethyltrimethylammonium bromide; GEL, gelatin; PEC, pectins; PEG, polyethylene glycol; PVP, polyvinylpyrrolidone; PVA, polyvinyl alcohol; SC, sodium citrate; SDS, sodium dodecyl sulfate, $\mathrm{CH}_{3}\left(\mathrm{CH}_{2}\right)_{11} \mathrm{OSO}_{3} \mathrm{Na}$; TCI, $\alpha$-thioglycerol.

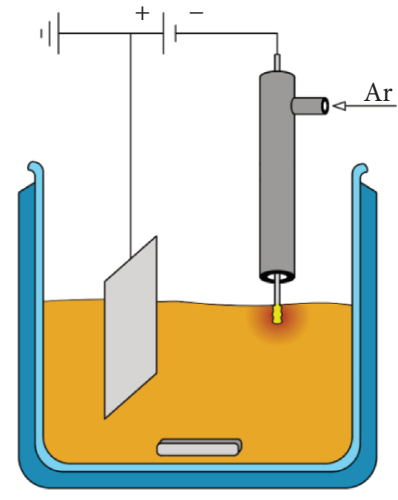

Figure 1: Scheme of the device for plasma synthesis of silver nanoparticles.

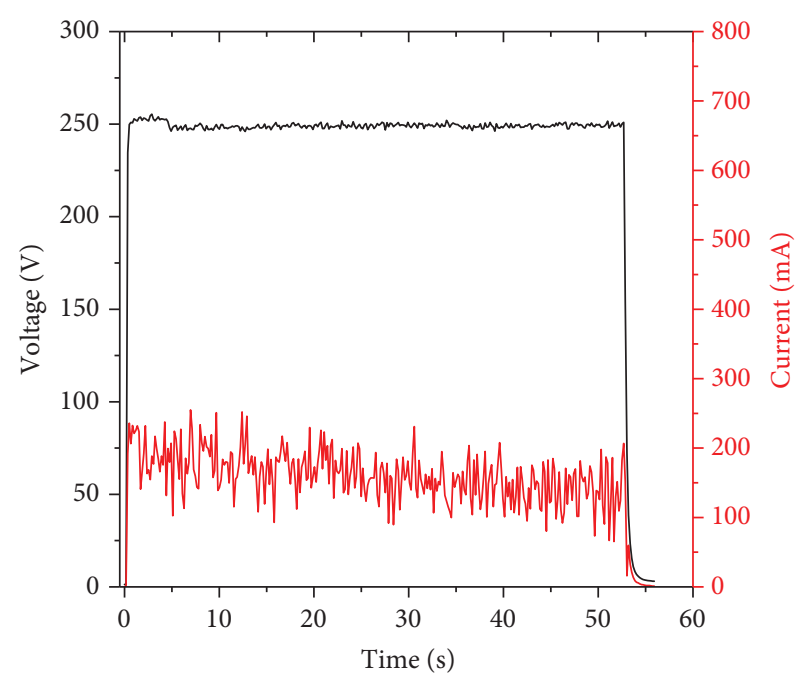

Figure 2: Changing of values of current and voltage over time during glow discharge in NaPA solution.

The UV-Vis spectra do not show intermediate absorption bands at 310 and $345 \mathrm{~nm}$ belonging to "magic" silver clusters of special stability $[55,56]$. Their formation is characteristic during the reduction of $\mathrm{Ag}(\mathrm{I})$ in NaPA solutions, and they are converted into nanoparticles with the formation of "blue silver" that is characterized by wide absorption bands at 490-530 nm [54-56]. This difference can be explained by the features of glow discharge synthesis, which causes a high concentration of active reducing agents ( $\mathrm{me}^{-}$aq, $\mathrm{mH}$, and $\mathrm{mH}_{2} \mathrm{O}_{2}$ ) in the solution volume and, accordingly, a high rate of $\mathrm{Ag}(\mathrm{I})$ reduction process and the formation of AgNCs and AgNPs (9). Under such conditions, the stability of the "magic" silver clusters, which are charged and contain a small number of $\mathrm{Ag}$ atoms $\left(\mathrm{Ag}_{8}{ }^{2+}, \mathrm{Ag}_{9}{ }^{+}\right)$[57], is complicated.

The nature of the UV-Vis spectra with the absorption maximum of $\sim 410 \mathrm{~nm}$ does not change in a wide concentration range of $\mathrm{AgNO}_{3}$ (Figures 4(a)-4(c)).

Increasing concentration of $\mathrm{AgNO}_{3}$ increases the increment of optical density value at $\lambda_{\max }=410 \mathrm{~nm}$ over time (Figure 5), which is identical to an increase in the formation rate of AgNPs (Figure 6).

Analysis of the obtained kinetic curves showed that the formation process of AgNPs during microplasma synthesis in the $\mathrm{AgNO}_{3}-\mathrm{NaPA}$ solutions corresponds to the following first-order reaction:

$$
\begin{gathered}
-\frac{d\left[\mathrm{Ag}^{+}\right]}{d t}=k \cdot\left[\mathrm{Ag}^{+}\right], \\
\ln \left(\left[\mathrm{Ag}^{+}\right]\right)=\ln \left(\left[\mathrm{Ag}^{+}\right]_{0}\right)-k \cdot t .
\end{gathered}
$$

The values of the rate constants of AgNPs formation process $\left(k_{G}\right)$ at initial $\mathrm{AgNO}_{3}$ concentrations of 0.05, 0.10, and $0.20 \mathrm{~mol} \mathrm{~L}^{-1}$ are close to $-0.212,0.207$, and $0.193 \mathrm{~min}^{-1}$, respectively.

The sizes of nanoparticles do not exceed $30 \mathrm{~nm}$ (Figure 7) and depend little on the concentration of $\mathrm{Ag}(\mathrm{I})$ ions. So, the latter can be considered one of the main factors influencing the rate of microplasma synthesis of stabilized silver nanoparticles.

As already mentioned, the value of the absorption maximum $(\sim 410 \mathrm{~nm})$ of the synthesized AgNPs solutions practically does not change during long-term storage (Figures 7(a) and 7(c) and 8).

All this indicates the stability of the geometry of the synthesized nanoparticles during long-term storage. 

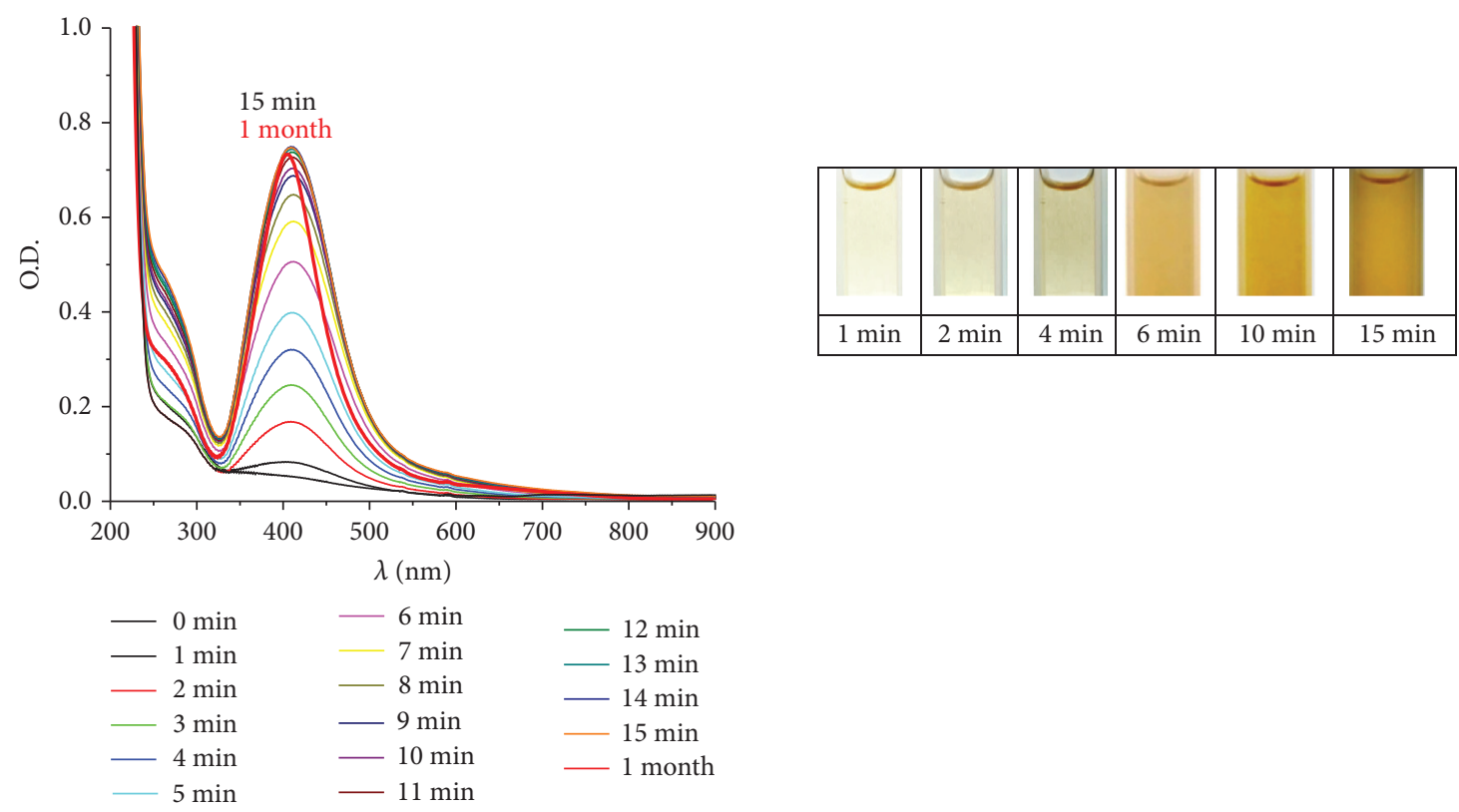

FIGURE 3: The UV-Vis spectra of AgNPs at different time points of synthesis by microplasma discharge in $0.1 \mathrm{mmol} \cdot \mathrm{L}^{-1} \mathrm{AgNO}{ }_{3}+\mathrm{NaPA}$ $\left(5 \mathrm{~g} \mathrm{~L}^{-1}\right)$ solution, $t=20^{\circ} \mathrm{C}$.

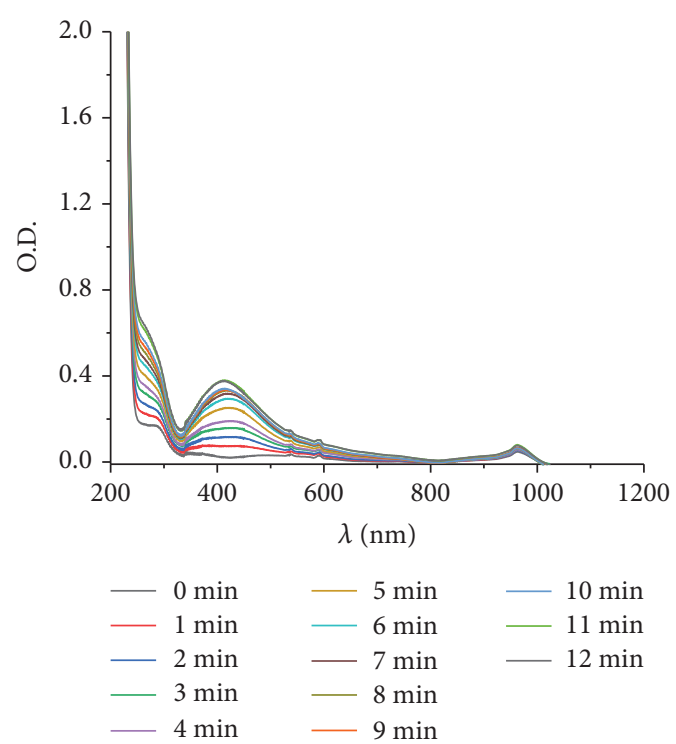

(a)

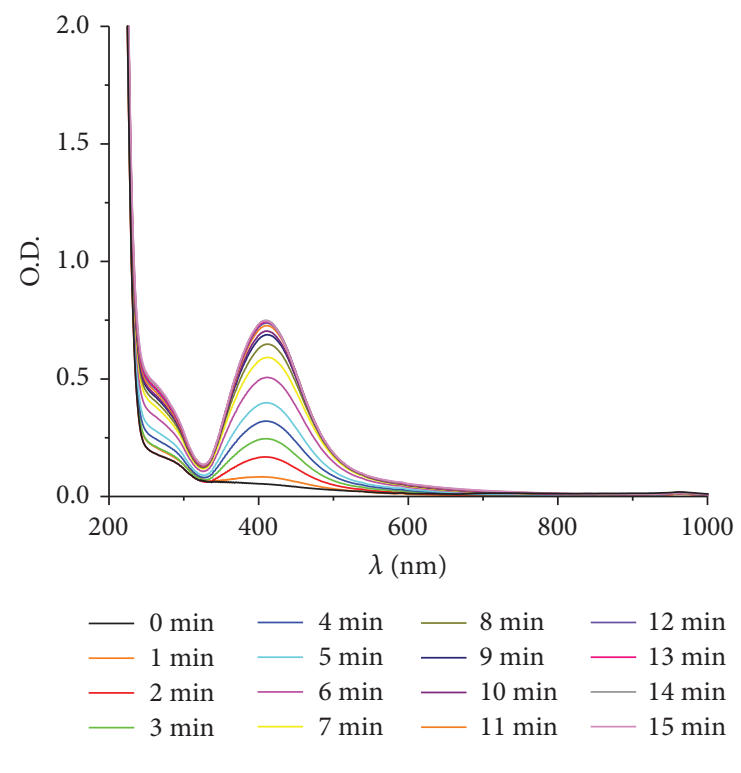

(b)

Figure 4: Continued. 


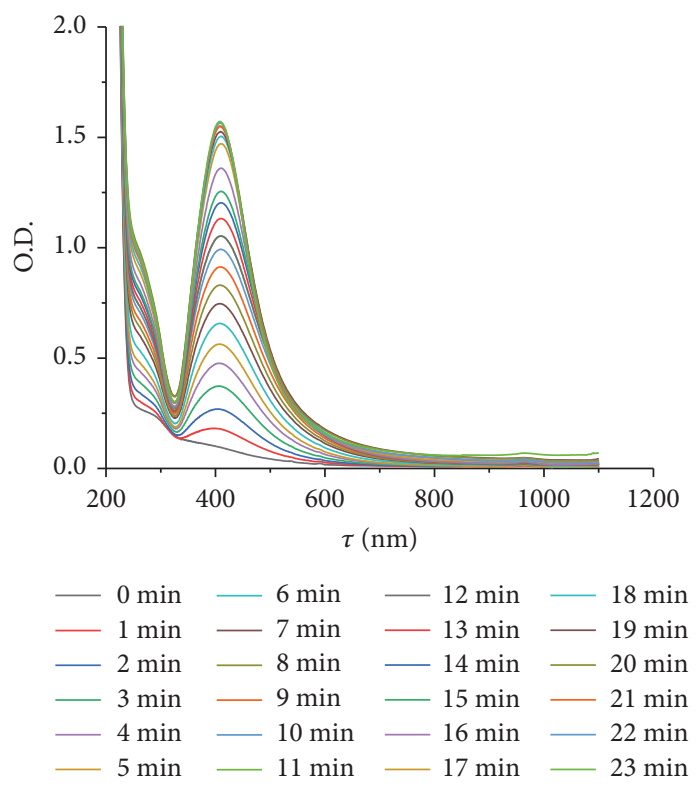

(c)

Figure 4: The UV-Vis spectra of AgNPs at different synthesis durations by microplasma discharge in $0.05 \mathrm{mmol} \mathrm{L}^{-1}$ (a), $0.1 \mathrm{mmol} \mathrm{L}^{-1}$ (b), and $0.2 \mathrm{mmol} \mathrm{L}^{-1}$ (c) $\mathrm{AgNO}_{3}$ in $5 \mathrm{~g} \cdot \mathrm{L}^{-1} \mathrm{NaPA}$ solution, $t=20^{\circ} \mathrm{C}$.

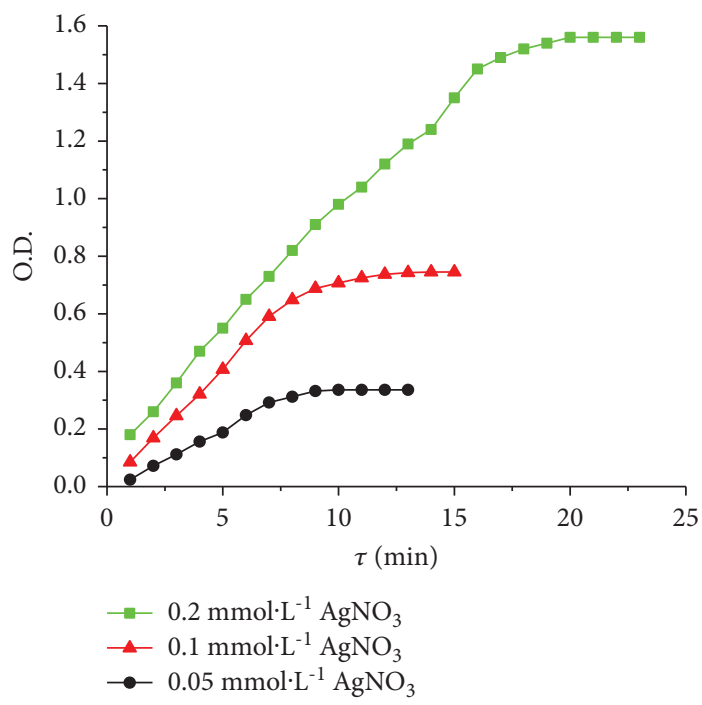

Figure 5: Dependences of the optical density of solutions at $\lambda_{\max }=410 \mathrm{~nm}$ on synthesis duration.

\section{Antibacterial Activity of Synthesized AgNPs}

The results of studies on the antibacterial properties of microplasma-synthesized AgNPs indicate their activity against Gram-positive bacteria Staphylococcus aureus ATCC No. 25923, Gram-negative bacteria Escherichia coli ATCC No. 25922 (Tables 2 and 3), and fungicidal bacteria Candida albicans ATCC No. 885-653 (Tables 4 and 5).

The Staphylococcus aureus ATCC 25923 strain is more resistant than the Escherichia coli ATCC 25922 and Candida albicans ATCC 885-653 strains. Thus, the bactericidal action of the synthesized colloidal AgNPs solutions against Staphylococcus aureus ATCC 25923 in the studied range of contact time $(1-48 \mathrm{~h})$ is manifested only when the concentration of the $\mathrm{AgNO}_{3}$ solution increases from 0.1 to $0.2 \mathrm{mmol} \mathrm{L}^{-1}$ (Tables 2 and 3 and Figure 9). Two different mechanisms can cause antibacterial and fungicidal properties of the synthesized AgNPs solutions: (1) fixation of silver nanoparticles on cell membranes and their penetration into the cell, followed by damage to the membrane and release of the cell contents; (2) release of $\mathrm{Ag}^{+}$ions, which have bactericidal and fungicidal properties [58, 59]. The authors [60] consider that silver nanoparticles have the maximum 


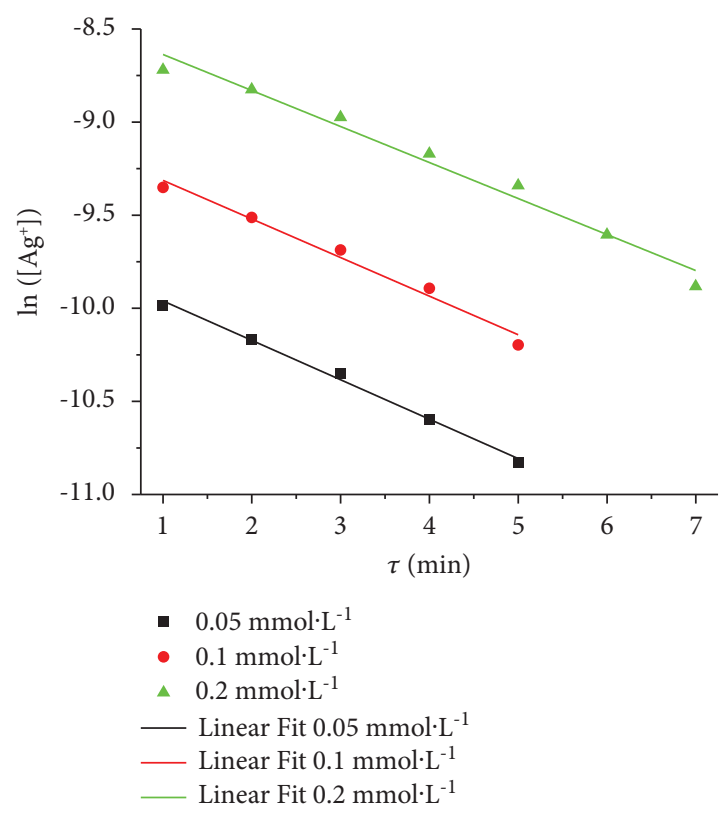

(a)

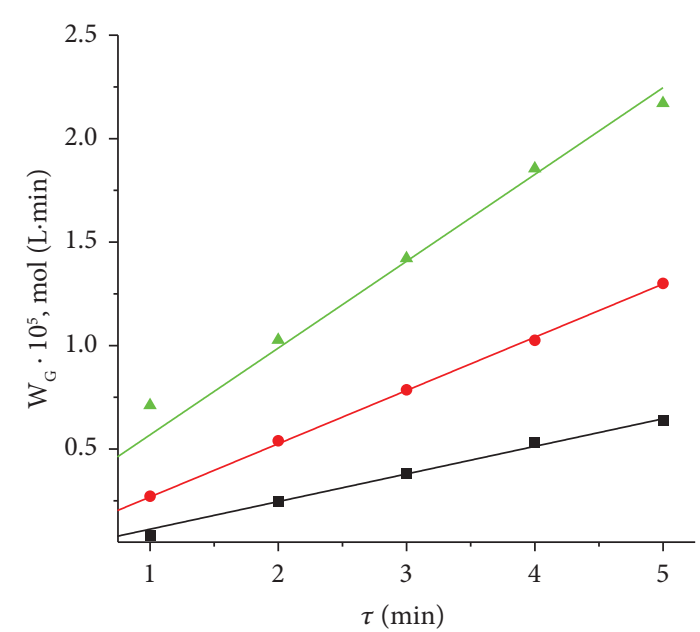

- $0.05 \mathrm{mmol} \cdot \mathrm{L}^{-1}$

- $0.1 \mathrm{mmol} \cdot \mathrm{L}^{-1}$

$\Delta 0.2 \mathrm{mmol} \cdot \mathrm{L}^{-1}$

— Linear Fit $0.05 \mathrm{mmol} \cdot \mathrm{L}^{-1}$

— Linear Fit $0.1 \mathrm{mmol} \cdot \mathrm{L}^{-1}$

— Linear Fit $0.2 \mathrm{mmol} \cdot \mathrm{L}^{-1}$

Figure 6: Kinetic curves of AgNP growth (a) and dependences of AgNP growth rate $\left(\mathrm{W}_{\mathrm{G}}\right)$ on synthesis duration (b) at different concentrations of $\mathrm{AgNO}_{3}$.

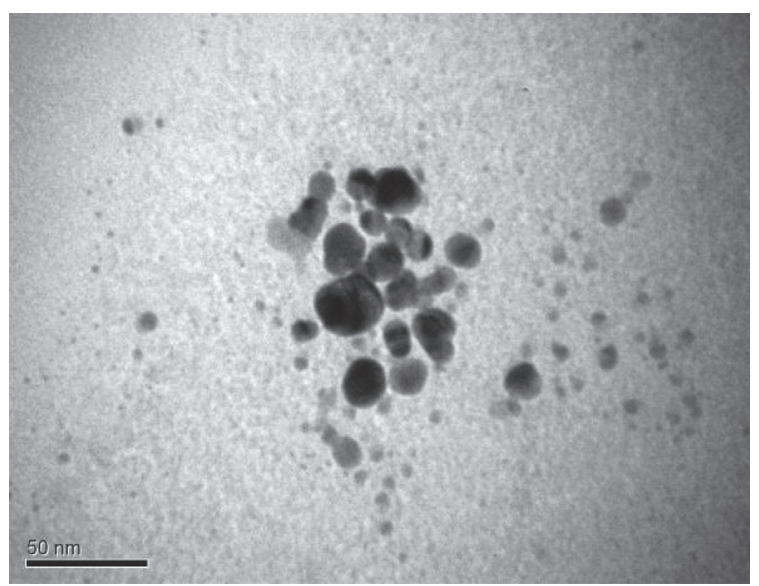

(a)

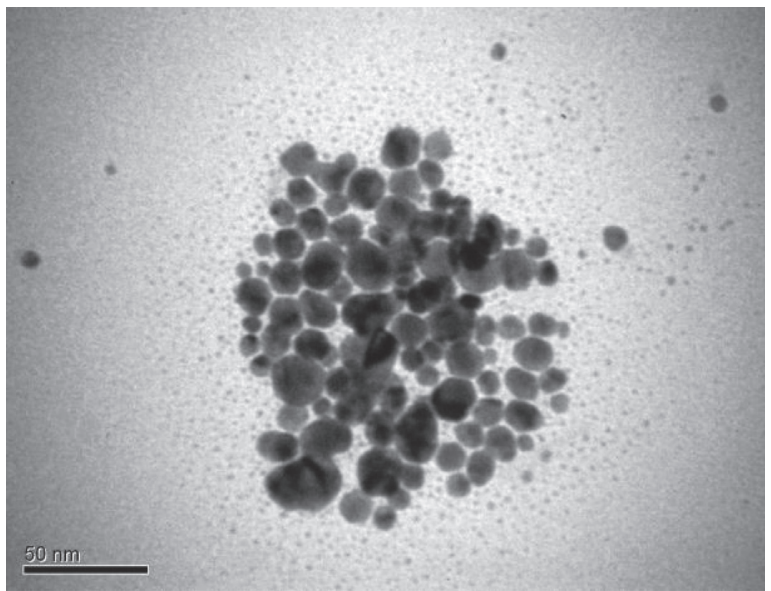

(c)

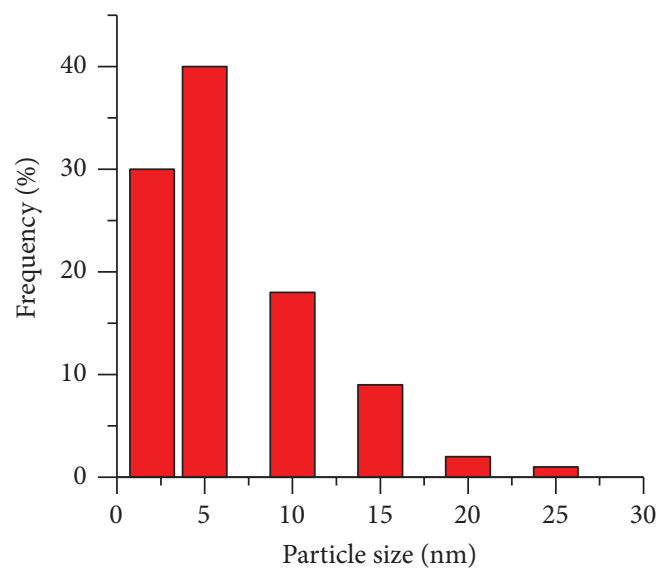

(b)

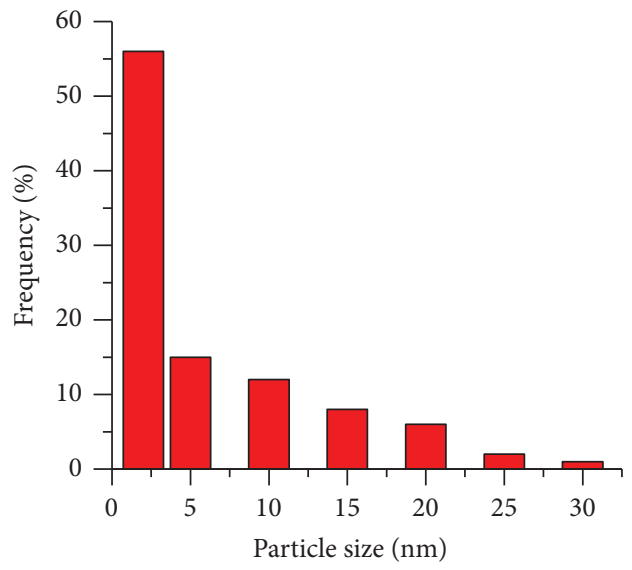

(d)

Figure 7: TEM images $(\mathrm{a}, \mathrm{c})$ and the size distribution histograms $(\mathrm{b}, \mathrm{d})$ of AgNPs, synthesized in $0.1 \mathrm{mmol} \cdot \mathrm{L}^{-1} \mathrm{AgNO}(\mathrm{a}, \mathrm{b})+5 \mathrm{~g} \cdot \mathrm{L}^{-1} \mathrm{NaPA}$ solution and $0.2 \mathrm{mmol} \cdot \mathrm{L}^{-1} \mathrm{AgNO} 3(\mathrm{c}, \mathrm{d})+5 \mathrm{~g} \cdot \mathrm{L}^{-1} \mathrm{NaPA}$ solution, $t=20^{\circ} \mathrm{C}$. 


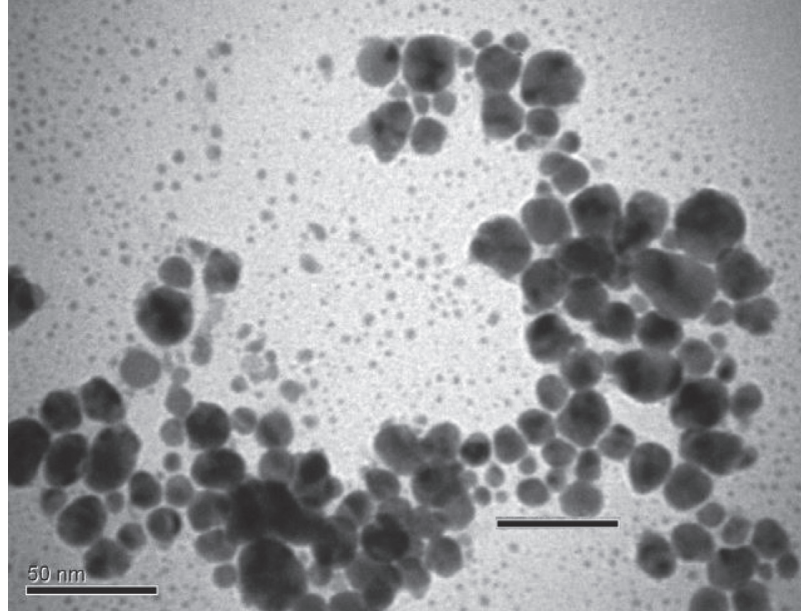

(a)

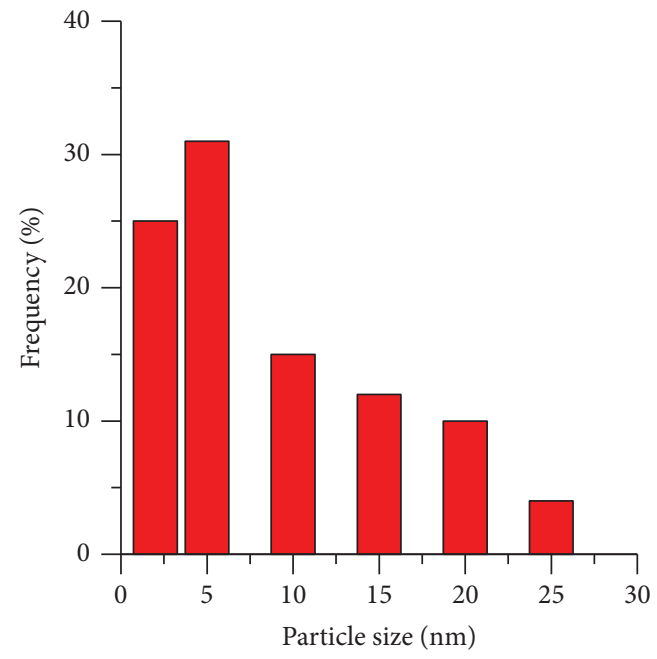

(b)

FIgURE 8: (a) TEM images of AgNPs after 1 month and (b) the size distribution histograms.

TABLE 2: Antibacterial properties of colloidal solutions of silver nanoparticles, synthesized by microplasma discharge in $0.1 \mathrm{mmol} \cdot \mathrm{L}^{-1}$ $\mathrm{AgNO}_{3}$ and stabilized with polyacrylate solutions.

\begin{tabular}{lccc}
\hline Species of bacteria & Exposure time $(\mathrm{h})$ & Quantity $\left(\mathrm{CFU} / \mathrm{cm}^{3}\right)$ & Bactericidal action \\
\hline & 1 & 120 & - \\
S. $a$ reus ATCC 25923 (F-49) & 6 & 50 & - \\
& 18 & 30 & - \\
& 48 & Not found & - \\
E. coli ATCC 25922 (F-50) & 1 & Not found & + \\
& 6 & Not found & + \\
\hline
\end{tabular}

CFU, colony-forming units; +, pronounced antimicrobial (disinfecting) effect (no growth of microorganisms); -, no antimicrobial (disinfectant) action (available growth of microorganisms).

TABLE 3: Antibacterial properties of colloidal solutions of silver nanoparticles, synthesized by microplasma discharge in $0.2 \mathrm{mmol} \cdot \mathrm{L}^{-1}$ $\mathrm{AgNO}_{3}$ and stabilized with polyacrylate solutions.

\begin{tabular}{lccc}
\hline Species of bacteria & Exposure time $(\mathrm{h})$ & Quantity $\left(\mathrm{CFU} / \mathrm{cm}^{3}\right)$ & Bactericidal action \\
\hline & 1 & 100 & 50 \\
\\
S. aureus ATCC 25923 (F-49) & 6 & Not found & - \\
& 18 & Not found & + \\
& 48 & Not found & + \\
E. coli ATCC 25922 (F-50) & 1 & Not found & + \\
& 6 & Not found & + \\
\end{tabular}

CFU, colony-forming units; +, pronounced antimicrobial (disinfecting) effect (no growth of microorganisms); -, no antimicrobial (disinfectant) action (available growth of microorganisms).

TABLE 4: Fungicidal properties of colloidal solutions of silver nanoparticles, synthesized by microplasma discharge in $0.1 \mathrm{mmol} \cdot \mathrm{L}^{-1} \mathrm{AgNO}_{3}$ and stabilized with polyacrylate solution.

\begin{tabular}{lccc}
\hline Species of mushrooms & Exposure time $(\mathrm{h})$ & Quantity $\left(\mathrm{CFU} / \mathrm{cm}^{3}\right)$ & Bactericidal action \\
\hline & 1 & 50 & - \\
Candida albicans ATCC 885-653 & 6 & 9 & Not found \\
& 18 & Not found & + \\
& 48 & + & + \\
\hline
\end{tabular}


TABLE 5: Fungicidal properties of colloidal solutions of silver nanoparticles, synthesized by microplasma discharge in $0.2 \mathrm{mmol} \cdot \mathrm{L}^{-1} \mathrm{AgNO}_{3}$ and stabilized with polyacrylate solution.

\begin{tabular}{lccc}
\hline Species of mushrooms & Exposure time $(\mathrm{h})$ & Quantity $\left(\mathrm{CFU} / \mathrm{cm}^{3}\right)$ & Bactericidal action \\
\hline & 1 & 40 & - \\
Candida albicans ATCC 885-653 & 6 & 8 & - \\
& 18 & Not found & + \\
& 48 & Not found & + \\
\hline
\end{tabular}

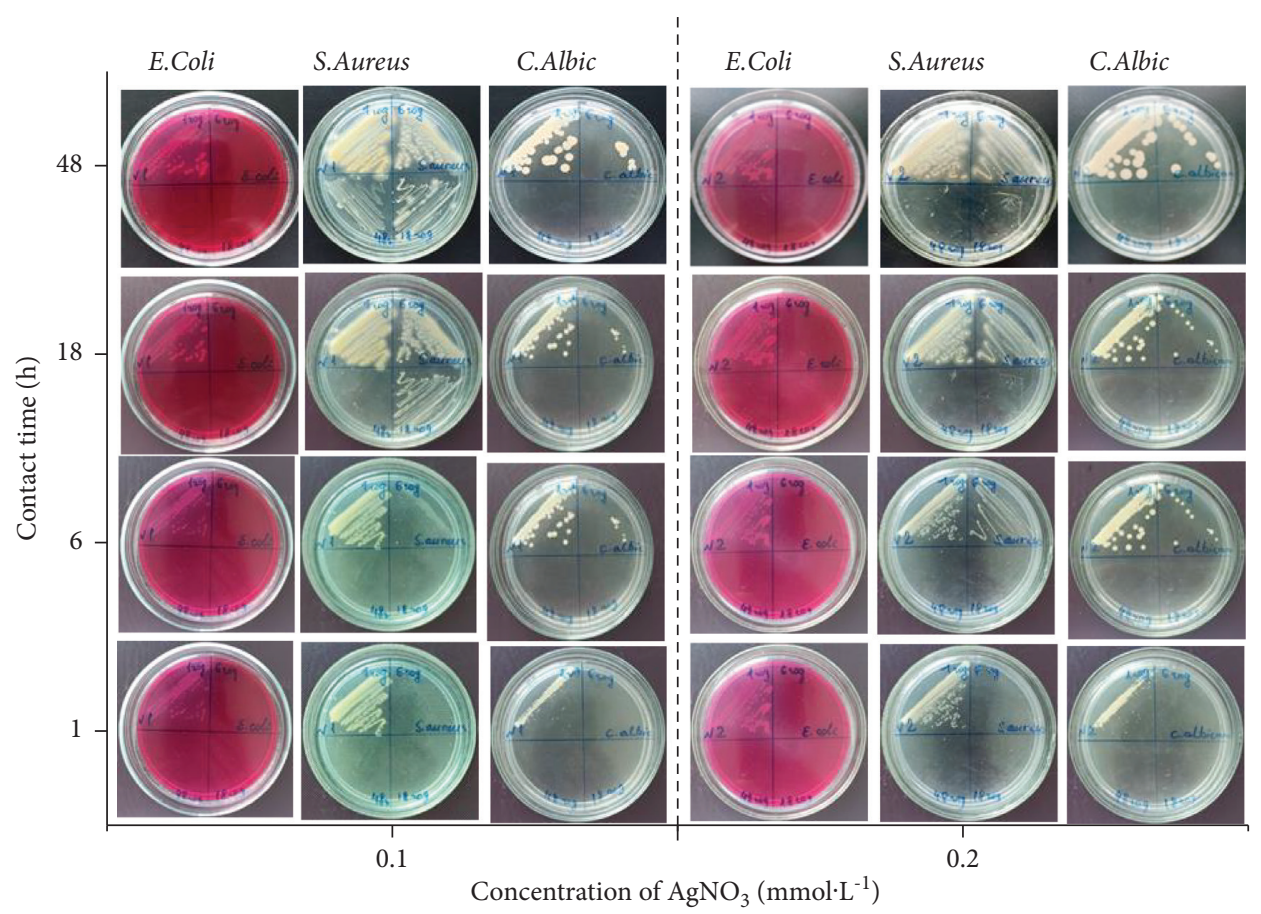

FIgure 9: Agar plate assays to assess the antibacterial activity of AgNPs with different concentrations $\left(\mathrm{mmol}^{-1} \mathrm{~L}^{-1}\right)$ of AgNPs and different contact time durations.

antimicrobial action with a size of less than $10 \mathrm{~nm}$, as shown in Figure $8(\mathrm{~b})$, and $58 \%$ of the silver nanoparticles obtained by microplasma synthesis have sizes less than $10 \mathrm{~nm}$.

\section{Conclusions}

In solutions of the nontoxic surfactant sodium polyacrylate (NaPA) and $\mathrm{AgNO}_{3}$ by tungsten cathode plasma glow discharge at $250 \mathrm{~V}$, the stabilized silver nanoparticles are formed. At the precursor's concentration of 0.05-0.2 mmol. $\mathrm{L}^{-1} \quad \mathrm{AgNO}_{3}+5 \mathrm{~g} \cdot \mathrm{L}^{-1} \mathrm{NaPA}$, AgNPs are formed with a size of $2-20 \mathrm{~nm}$. At $20^{\circ} \mathrm{C}$, the yellow solutions are formed with $\lambda_{\max } \approx 410 \mathrm{~nm}$, which are stable during long-term storage. The process of AgNP formation corresponds to a first-order reaction in the $\mathrm{AgNO}_{3}$ concentration. The latter value has little effect on the geometry of nanoparticles, so the $\mathrm{Ag}(\mathrm{I})$ concentration in solution is one of the main factors influencing the rate of microplasma synthesis of AgNPs. The antimicrobial activity of synthesized AgNPs solutions against strains of Escherichia coli, Staphylococcus aureus, and Candida albicans was established.

\section{Data Availability}

The data used to support the findings of this study are included within the article.

\section{Conflicts of Interest}

The authors declare that there are no conflicts of interest regarding the publication of this paper.

\section{Acknowledgments}

This work was carried out with the partial financial support of the National Research Foundation of Ukraine under project registration number 2020.02/0309 ("Design of Polyfunctional Nanostructured Mono- and Bimetals with Electrocatalytic and Antimicrobial Properties").

\section{References}

[1] C. Liao, Y. Li, and S. Tjong, "Bactericidal and cytotoxic properties of silver nanoparticles," International Journal of Molecular Sciences, vol. 20, no. 2, pp. 449-495, 2019. 
[2] S. M. Mousavi, S. A. Hashemi, and Y. Ghasemi, “"'Green synthesis of silver nanoparticles toward bio and medical applications: review study," Artificial Cells," Nanomedicine, and Biotechnology, vol. 46, pp. 855-872, 2018.

[3] H. Katas, N. Z. Moden, and C. S. Lim, "Biosynthesis and potential applications of silver and gold nanoparticles and their chitosan-based nanocomposites in nanomedicine," Journal of Nanotechnology, vol. 2018, Article ID 4290705, 13 pages, 2018.

[4] M. Sabela, S. Balme, M. Bechelany, J.-M. Janot, and K. Bisetty, "A review of gold and silver nanoparticle-based colorimetric sensing assays," Advanced Engineering Materials, vol. 19, no. 12, p. 24, Article ID 1700270, 2017.

[5] G. Shimoga, R. R. Palem, S.-H. Lee, and S.-Y. Kim, "Catalytic degradability of p-nitrophenol using ecofriendly silver nanoparticles," Metals, vol. 10, no. 12, p. 20, Article ID 1661, 2020.

[6] H. Bahrulolum, S. Nooraei, and N. Javanshir, "Green synthesis of metal nanoparticles using microorganisms and their application in the agrifood sector," Journal of Nanobiotechnology, vol. 19, no. 1, p. 26, Article ID 86, 2021.

[7] M. Nasrollahzadeh, S. Mahmoudi-Gom Yek, N. Motahharifar, and M. Ghafori Gorab, "Recent developments in the plant-mediated green synthesis of Ag-based nanoparticles for environmental and catalytic applications," The Chemical Record, vol. 19, no. 12, pp. 2436-2479, 2019.

[8] S. S. Salem and A. Fouda, "Green synthesis of metallic nanoparticles and their prospective biotechnological applications: an overview," Biological Trace Element Research, vol. 199, no. 1, pp. 344-370, 2021.

[9] M. Guilger-Casagrande and R. De Lima, "Synthesis of silver nanoparticles mediated by fungi: a review," Frontiers in Bioengineering and Biotechnology, vol. 7, p. 16, Article ID 287, 2019.

[10] F. Foroughi, J. J. Lamb, O. S. Burheim, and B. G. Pollet, "Sonochemical and sonoelectrochemical production of energy materials," Catalysts, vol. 11, no. 2, Article ID 284, 2021.

[11] L. Lin and Q. Wang, "Microplasma: a new generation of technology for functional nanomaterial synthesis," Plasma Chemistry and Plasma Processing, vol. 35, no. 6, pp. 925-962, 2015.

[12] G. Saito and T. Akiyama, "Nanomaterial synthesis using plasma generation in liquid," Journal of Nanomaterials, vol. 2015, p. 21, Article ID 123696, 2015.

[13] L. Di, J. Zhang, and X. Zhang, "A review on the recent progress, challenges, and perspectives of atmospheric-pressure cold plasma for preparation of supported metal catalysts," Plasma Processes and Polymers, vol. 15, no. 5, p. 19, Article ID 1700234, 2018.

[14] J. Weerasinghe, W. Li, R. Zhou et al., "Bactericidal silver nanoparticles by atmospheric pressure solution plasma processing," Nanomaterials, vol. 10, no. 5, p. 10, Article ID 874, 2020.

[15] S. M. Abdallah, A. M. Alwan, and R. A. Khamis, "Effect of discharge time on the size control of AgNPs prepared by nonthermal atmospheric plasma discharge," Journal of Materials Science: Materials in Electronics, vol. 30, no. 13, pp. 1263012638, 2019.

[16] C. De Vos, J. Baneton, and M. Witzke, "A comparative study of the reduction of silver and gold salts in water by a cathodic microplasma electrode," Journal of Physics D: Applied Physics, vol. 50, no. 10, p. 11, Article ID 105206, 2017.

[17] P. Lu, D.-W. Kim, and D.-W. Park, "Simple reactor for the synthesis of silver nanoparticles with the assistance of ethanol by gas-liquid discharge plasma," Plasma Science and Technology, vol. 21, no. 4, p. 18, Article ID 044005, 2019.

[18] O. I. Kuntyi, A. R. Kytsya, A. B. Bondarenko, A. S. Mazur, I. P. Mertsalo, and L. I. Bazylyak, "Microplasma synthesis of silver nanoparticles in PVP solutions using sacrificial silver anodes," Colloid \& Polymer Science, vol. 299, no. 5, pp. 855-863, 2021.

[19] A. Dzimitrowicz, A. Motyka, P. Jamroz et al., "Application of silver nanostructures synthesized by cold atmospheric pressure plasma for inactivation of bacterial phytopathogens from the genera dickeya and pectobacterium," Materials, vol. 11, no. 3, p. 331, 2018.

[20] H.-J. Kim, J.-G. Shin, C.-S. Park et al., "In-Liquid plasma process for size- and shape-controlled synthesis of silver nanoparticles by controlling gas bubbles in water," Materials, vol. 11, no. 6, p. 891, 2018.

[21] X. L. Hu, O. Takai, and N. Saito, "Synthesis of gold nanoparticles by solution plasma sputtering in various solvents," Journal of Physics: Conference Series, vol. 417, p. 5, Article ID 012030, 2013.

[22] M. Yamada, S. Machmudah, H. Kanda, Y. Zhao, and M. Goto, "Atmospheric-pressure pulsed discharge plasma in a slug flow reactor system for the synthesis of gold nanoparticles," ACS Omega, vol. 5, no. 28, pp. 17679-17685, 2020.

[23] J. Patel, L. Němcová, P. Maguire, W. G. Graham, and D. Mariotti, "Synthesis of surfactant-free electrostatically stabilized gold nanoparticles by plasma-induced liquid chemistry," Nanotechnology, vol. 24, no. 24, Article ID 245604, 2013.

[24] A. Dzimitrowicz, A. Bielawska-Pohl, P. Pohl et al., "Application of oil-in-water nanoemulsion carrying size-defined gold nanoparticles synthesized by non-thermal plasma for the human breast cancer cell lines migration and apoptosis," Plasma Chemistry and Plasma Processing, vol. 40, no. 4, pp. 1037-1062, 2020.

[25] A. Dzimitrowicz, P. Jamroz, K. Greda, P. Nowak, M. Nyk, and P. Pohl, "The influence of stabilizers on the production of gold nanoparticles by direct current atmospheric pressure glow microdischarge generated in contact with liquid flowing cathode," Journal of Nanoparticle Research, vol. 17, no. 4, p. 10, Article ID 185, 2015.

[26] N. Saito, J. Hieda, and O. Takai, "Synthesis process of gold nanoparticles in solution plasma," Thin Solid Films, vol. 518, no. 3, pp. 912-917, 2009.

[27] P. Xie, Y. Qi, R. Wang, J. Wu, and X. Li, “Aqueous gold nanoparticles generated by $\mathrm{AC}$ and pulse-power-driven plasma jet," Nanomaterials, vol. 9, no. 10, p. 18, Article ID 1488, 2019.

[28] X. Huang, Y. Li, and X. Zhong, "Effect of experimental conditions on size control of Au nanoparticles synthesized by atmospheric microplasma electrochemistry," Nanoscale Research Letters, vol. 9, no. 1, p. 572, Article ID 572, 2014.

[29] G. Horiguchi, Y. Chikaoka, H. Shiroishi et al., "Synthesis of Pt nanoparticles as catalysts of oxygen reduction with microbubble-assisted low-voltage and low-frequency solution plasma processing," Journal of Power Sources, vol. 382, pp. 69-76, 2018.

[30] J.-F. Sauvageau, S. Turgeon, P. Chevallier, and M.-A. Fortin, "Colloidal suspensions of platinum group metal nanoparticles (Pt, Pd, Rh) synthesized by dielectric barrier discharge plasma (DBD)," Particle \& Particle Systems Characterization, vol. 35, no. 4, p. 11, Article ID 1700365, 2018.

[31] P. Pootawang, N. Saito, and S. Y. Lee, "Discharge time dependence of a solution plasma process for colloidal copper 
nanoparticle synthesis and particle characteristics," Nanotechnology, vol. 24, no. 5, Article ID 055604, 2013.

[32] A. M. El-Khatib, M. S. Badawi, G. D. Roston, R. M. Moussa, and M. M. Mohamed, "Structural and magnetic properties of nickel nanoparticles prepared by arc discharge method using an ultrasonic nebulizer," Journal of Cluster Science, vol. 29, no. 2, pp. 1321-1327, 2018.

[33] H. Lee, M. Chung, H.-G. Ahn, S.-J. Kim, Y.-K. Park, and S.-C. Jung, "Effect of the surfactant on size of nickel nanoparticles generated by liquid-phase plasma method," International Journal of Precision Engineering and Manufacturing, vol. 16, no. 7, pp. 1305-1310, 2015.

[34] A. M. Khalil, A. M. El-Khatib, and M. El-Khatib, "Synthesis of hexagonal nanozinc by arc discharge for antibacterial water treatment," Surface Innovations, vol. 8, no. 3, pp. 165-171, 2020.

[35] H.-G. Kim, H. Lee, S.-J. Kim et al., "Synthesis of manganese nanoparticles in the liquid phase plasma," Journal of Nanoscience and Nanotechnology, vol. 13, no. 9, pp. 6103-6108, 2013.

[36] S.-M. Kim, A.-R. Cho, and S.-Y. Lee, "Characterization and electrocatalytic activity of $\mathrm{Pt}-\mathrm{M}(\mathrm{M}=\mathrm{Cu}, \mathrm{Ag}$, and $\mathrm{Pd})$ bimetallic nanoparticles synthesized by pulsed plasma discharge in water," Journal of Nanoparticle Research, vol. 17, no. 7, p. 13, Article ID 284, 2015.

[37] S.-M. Kim, Y.-G. Jo, and S.-Y. Lee, "The composition-controlled synthesis of Pt-Ag bimetallic nanochains for catalytic methanol oxidation," Electrochimica Acta, vol. 174, pp. 1244-1252, 2015.

[38] P. Pootawang, N. Saito, O. Takai, and S. Y. Lee, "Synthesis and characteristics of $\mathrm{Ag} / \mathrm{Pt}$ bimetallic nanocomposites by arcdischarge solution plasma processing," Nanotechnology, vol. 23, no. 39, Article ID 395602, 2012.

[39] S.-M. Kim, Y.-J. Lee, J.-W. Kim, and S.-Y. Lee, "Facile synthesis of Pt-Pd bimetallic nanoparticles by plasma discharge in liquid and their electrocatalytic activity toward methanol oxidation in alkaline media," Thin Solid Films, vol. 572, pp. 260-265, 2014.

[40] X. Hu, X. Shen, O. Takai, and N. Saito, "Facile fabrication of PtAu alloy clusters using solution plasma sputtering and their electrocatalytic activity," Journal of Alloys and Compounds, vol. 552, no. 22, pp. 351-355, 2013.

[41] H. Shirai, M. T. Nguyen, D. Čempel et al., "Preparation of Au/ Pd bimetallic nanoparticles by a microwave-induced plasma in liquid process," Bulletin of the Chemical Society of Japan, vol. 90, no. 3, pp. 279-285, 2017.

[42] S. H. Sun and S.-C. Jung, "Facile synthesis of bimetallic Ni-Cu nanoparticles using liquid phase plasma method," Korean Journal of Chemical Engineering, vol. 33, no. 3, pp. 1075-1079, 2016.

[43] M. Trad, A. Nominé, C. Noël, J. Ghanbaja, M. Tabbal, and T. Belmonte, "Evidence of alloy formation in CoNi nanoparticles synthesized by nanosecond-pulsed discharges in liquid nitrogen," plasma processes and polymers," Plasma Synthesis of Nanoparticles and Nanocomposite Coatings, vol. 17, no. 5, p. 11, Article ID 1900255, 2020.

[44] G. Saito, Y. Nakasugi, T. Yamashita, and T. Akiyama, "Solution plasma synthesis of bimetallic nanoparticles," Nanotechnology, vol. 25, Article ID 135603, 2014.

[45] N. T. K. Thanh, N. Maclean, and S. Mahiddine, "Mechanisms of nucleation and growth of nanoparticles in solution," Chemical Reviews, vol. 114, no. 15, pp. 7610-7630, 2014

[46] S. Mozaffari, W. Li, C. Thompson et al., "Colloidal nanoparticle size control: experimental and kinetic modeling investigation of the ligand-metal binding role in controlling the nucleation and growth kinetics," Nanoscale, vol. 9, no. 36, pp. 13772-13785, 2017.

[47] S. Das, K. Bandyopadhyay, and M. M. Ghosh, "Effect of stabilizer concentration on the size of silver nanoparticles synthesized through chemical route," Inorganic Chemistry Communications, vol. 123, p. 6, Article ID 108319, 2021.

[48] K. M. Koczkur, S. Mourdikoudis, L. Polavarapu, and S. E. Skrabalak, "Polyvinylpyrrolidone (PVP) in nanoparticle synthesis," Dalton Transactions, vol. 44, no. 41, pp. 17883-17905, 2015.

[49] M. Tejamaya, I. Römer, R. C. Merrifield, and J. R. Lead, "Stability of citrate, PVP, and PEG coated silver nanoparticles in ecotoxicology media," Environmental Science \& Technology, vol. 46, no. 13, pp. 7011-7017, 2012.

[50] A. Panáček, R. Prucek, and J. Hrbáč, "Polyacrylate-assisted size control of silver nanoparticles and their catalytic activity," Chemistry of Materials, vol. 26, pp. 1332-1339, 2014.

[51] A. Ezhova and K. Huber, "Specific interactions of Ag+ ions with anionic polyacrylate chains in dilute solution," Macromolecules, vol. 47, no. 22, pp. 8002-8011, 2014.

[52] A. Kyrychenko, M. M. Blazhynska, M. V. Slavgorodska, and O. N. Kalugin, "Stimuli-responsive adsorption of poly(acrylic acid) onto silver nanoparticles: role of polymer chain length and degree of ionization," Journal of Molecular Liquids, vol. 276, pp. 243-254, 2019.

[53] A. Urbanski, M. Hansch, and C. G. Lopez, "Polyacrylates in the presence of an extraordinary monovalent cation-Solution behavior and metal nanoparticle formation," The Journal of Chemical Physics, vol. 149, no. 16, p. 11, Article ID 163318, 2018.

[54] O. I. Kuntyi, A. R. Kytsya, I. P. Mertsalo et al., "Electrochemical synthesis of silver nanoparticles by reversible current in solutions of sodium polyacrylate," Colloid \& Polymer Science, vol. 297, no. 5, pp. 689-695, 2019.

[55] B. G. Ershov and A. Henglein, "Reduction of Ag+ on polyacrylate chains in aqueous solution," The Journal of Physical Chemistry B, vol. 102, no. 52, pp. 10663-10666, 1998.

[56] O. Kuntyi, M. Shepida, and M. Sozanskyi, "Sonoelectrochemical synthesis of silver nanoparticles in sodium polyacrylate solution," Biointerface Research in Applied Chemistry, vol. 11, no. 4, pp. 12202-12214, 2021.

[57] B. G. Ershov, E. Janata, and A. Henglein, "Growth of silver particles in aqueous solution: long-lived "magic" clusters and ionic strength effects," The Journal of Physical Chemistry, vol. 97, no. 2, pp. 339-343, 1993.

[58] M. Shepida, O. Kuntyi, M. Sozanskyi, and Y. Sukhatskiy, "Sonoelectrochemical synthesis of antibacterial active silver nanoparticles in rhamnolipid solution," Advances in Materials Science and Engineering, vol. 2021, Article ID 7754523, 9 pages, 2021.

[59] S. Rajeshkumar and C. Malarkodi, "In vitro antibacterial activity and mechanism of silver nanoparticles against foodborne pathogens," Bioinorganic Chemistry and Applications, vol. 2014, Article ID 581890, 10 pages, 2014.

[60] S. J. Nurani, C. K. Saha, Md.A. R. Khan, and S. M. H. Sunny, "Silver nanoparticles synthesis, properties, applications and future perspectives: a short review," IOSR Journal of Electrical and Electronics Engineering, vol. 10, pp. 117-126, 2015. 